\title{
SERPENT WORSHIP AND ISLAM IN EGYPT
}

IN SPITE of the exclusiveness of Islam, and the fact that Egypt is the intellectual center of the system, traces of the serpent worship of the ancient Egyptians are still to be found, and in one case it is practiced with the sanction of the Moslem faith.

The superstitious idea that every house has a serpent guardian is pretty general throughout the country, and many families still provide a bowl of milk for their serpent protector, believing calamity would come upon them if the serpent were neglected. This is undoubtedly a survival of the ancient belief that the serpent was the child of the earth - the oldest inhabitant of the land, and guardian of the ground.

The serpent is used very frequently by sorcerers in their incantations, and also in the preparation of medicines and philtres, which are used for the cure of physical and emotional disturbances suffered by their clients.

The religious sanction given to serpent worship, occurs in the case of Sheikh Heridi whose tomb or shrine, with that of his wife, is to be seen in the mountains of Upper Egypt some distance from the town of Akhmin. Sheikh Heridi is really a serpent supposed to occupy one of the tombs. The birthday festival of this serpent saint takes place during the month following Ramadhan, and lasts about eight days. This festival is attended by crowds of devotees, including large numbers of sailors who encamp round about the shrine during the festivities.

At other times pilgrimages on behalf of those suffering from certain ailments are made to the sacred tomb. Professor Sayce in an article on the subject published in the "Contemporary Review" for October, 1893 quotes at length from various travellers who have mentioned the serpent saint of Islam in their writings. The first writer-Paul Lucas-who travelled in the East by order 
of Louis XIV in 1714 , in one of his books gives a description of the worship of the serpent by Moslems, and records instances of its miraculous powers. His story was discredited in France, so in order to confirm what he had heard he decided to visit the shrine himself. Near Tahta he made the acquaintance of a certain Bey, who sent for the Dervish saint with whom the serpent was living. The Dervish came bringing the serpent with him. The Bey took the creature which Lucas declares was of normal size and very tame, and placed it in his breast. The Bey and the Dervish then told Lucas many stories of the snake's miraculous power, one of the most remarkable of which was the story of a woman of Akhmin. She had suffered from paralysis for eight years and could find no cure. She begged her friend to carry her to the shrine of the serpent-saint where she believed she would be healed. At last her friends consented to take her. A rough litter was made and the journey commenced. While the bearers were resting on the way, a snake was seen to crawl into the litter. The men, fearing that it was sent to punish the woman for some sin, ran away. After a time they came back and saw the snake crawl away, and found the woman quite cured of the disease.

When several stories had been told, the Dervish begged to be allowed to return to the shrine. The Bey said he wished to keep the serpent for a few days: but the Dervish said that it had already got back to the shrine. The Bey searched high and low for it, and failing to find it, sent a messenger with the Dervish to find out whether the creature had really got back. Half an hour later the messenger returned saying that the serpent had indeed got back to its shrine, and had advanced about twenty steps to meet the Dervish l

Another quotation is from a book by Norden, the Dane, who sailed up the Nile in I737. Norden tells us that the Arabs believed that God by special favor transformed the dead Sheikh Heridi, who was buried in the place where the serpent lived, into a serpent which could never die, and which had the power of curing certain 
maladies, and of granting favors to all who implored for them and made sacrifices to the saint. They believed that it made some distinction between rich and poor. If a rich man desired its presence, it graciously attended with but little persuasion, but a poor person who needed its ministration had to promise to recompense the serpent for its trouble. It was necessary too, that intercession on behalf of a poor person should be made by a virgin of spotless character, on whose bosom the spirit would condescend to be carried to the sufferer. If during the performance of a miracle a Christian or other infidel should appear the snake would immediately disappear. If the creature should be cut to pieces, the pieces would straighten and unite again because it was eternal.

The Christians declared the saint to be really a demon who was allowed by God to deceive the ignorant. And they had a tradition that it was to this place the angel Raphael banished the devil Asmodens mentioned in the book of Tobit.

Thomas Legh, who journeyed up the Nile in 1812 makes mention of the miracles of Sheikh Heridi. And in 1822 Sir Frederick Henniker described the district in which the shrine is built, and speaks of the veneration the Arabs have for the serpent.

Professor Sayce then describes in detail the immediate surroundings of the two domed shrines, one of which belongs to the wife of the serpent. Near the shrine is a cleft of the rock which was probably the grotto inhabited by the saint before the shrine was erected.

Sheikh Heridi occupies as high a place in the esteem of the native today, as he did in the days of Paul Lucas, and Norden. His birthday festival is attended by crowds of devoted believers. Many stories are still told of the miraculous powers of the saint, who is declared to be a serpent as "thick as a man's thigh." If treated with irreverence or disrespect, it breathes fire into the face of the offender who forthwith dies. It is as jealous of its "wife's" good name; those who show her disrespect are also put to death by the saint. The belief that if the serpent is hacked to pieces each piece 
will rejoin, still survives, and it is held that any one clever enough to note the place where the blood flowed would become wealthy, because there he would find gold.

The professor points out that Sheikh Heridi may be regarded as the successor of Agathodaemon-the ancient serpent god of healing. Belief in his miraculous powers is as strong today as it was in the days of the Rameses or Ptolemies. The name only is changed. The modern Moslem who attends the mulid of the "saint" and implores assistance or blessing, is scarcely to be distinguished from his ancient ancestor who worshipped the serpent god.

At the entrance to the quarry through which pilgrims have to pass on their way to the shrine, Professor Sayce discovered engraved in large Greek letters in the stone the words Eח' ATA@ת, which, he says, indicate that during the Greek period, the place was sacred, and that a divinity must have been worshipped here. It may be safely assumed that that divinity was none other than the sacred serpent Sheikh Heridi under another name.

In spite of their intolerant policy, and bitter exclusiveness Islam has failed to root out the influence of the old paganism; she does not bring enlightenment to those who sit in darkness and in the shadow of death.

\section{BIBLIOGRAPHY}

"Serpent worship in ancient and modern Egypt." By Professor A. H.

Sayce. "Contemporary Review," October, 1893.

In this article the Professor quotes from the following books-

1. "Voyage du Sieur Paul Lucas, fait en MDCCXIV dans la Turquie, etc."

2. "Voyage d'Egypte et de Nubie." Frederic-Louis Norden, 1795 A. D.

3. "Narrative of a Journey in Egypt, etc." Thomas Legh, 1814 A. D.

4. "Notes during a Visit in Egypt," etc. Sir Fred F. Henniker, 1823 A. D.

Havre, France.

H. E. E. HAYES.

The subject is also briefly treated in "The Religion of Ancient Egypt." Prof. A. H. Sayce, I9r3 A. D. 